\title{
Sosialisasi dan implementasi perangkat pembelajaran matematika dalam mendukung keterampilan abad 21
}

\section{Nyoman Sridana1, Arjudin², Amrullah ${ }^{3}$, Muhammad Turmuzi ${ }^{4}$, Junaidi ${ }^{5 *}$}

1,2,3,4,5 Pendidikan Matematika, FKIP, Universitas Mataram, Mataram

junaidi88@unram.ac.id

\begin{abstract}
Lack of knowledge in a number of teachers who are not able to operate the concept of learning well, namely teachers only rely on learning methods and strategies on the handbook or documents that have been received. The impact of learners has difficulty in solving problems. By utilizing the results of research on the development of mathematical learning tools in the form of teaching materials, LKPD, and RPP based on 21st century skills that are feasible to be used can solve the problem. Therefore, it is necessary to socialize and implement the results of the research to the community, especially teachers in junior high schools. the outer target of this agility is the understanding for teachers of 21st century skill-based learning tools, particularly mathematics and other subjects
\end{abstract}

Keywords: 21st Century Devices; 21st Century skills.

\begin{abstract}
Abstrak
Kurangnya pengetahuan pada sejumlah guru yang tidak mampu mengoperasionalkan konsep pembelajaran dengan baik, yakni guru-guru hanya menggantungkan metode dan strategi pembelajaran pada buku pegangan atau dokumen-dokumen yang sudah diterima. Dampaknya peserta didik mengalami kesulitan dalam pemecahan masalah. Dengan memanfaatkan hasil penelitian pengembangan perangkat pembelajaran matematika yang berupa bahan ajar, LKPD, dan RPP berbasis keterampilan abad 21 yang layak digunakan dapat mengatasi permasalahan tersebut. Sehingga perlu diadakan sosialisasi dan implementasi terhadap hasil penelitian tersebut kepada masyarakat, khususnya para guru di sekolah menengah pertama. target luaran dari kegaitan ini adalah pemahaman bagi guru-guru tentang perangkat pembelajaran berbasis keterampilan abad 21, khususnya matematika dan mata pelajaran lain.
\end{abstract}

Kata Kunci: Perangkat Abad 21; Keterampilan Abad 21.

\section{PENDAHULUAN}

Keterampilan Abad 21 yang dianggap bisa memperkuat modal sosial (social capital) dan modal intelektual (intellectual capital) ini, biasa disingkat dengan 4C: communication, collaboration, critical thinking and problem solving, dan creativity and innovation. Kemampuan komunikasi, berpikir kreatif dan disposisi matematis merupakan kemampuan yang sangat penting dimiliki oleh setiap siswa dalam pembelajaran matematika (Choridah, 2013) mengapa kemampuan ini penting karena dengan komunikasi matematis siswa dapat mengorganisasikan berpikir matematisnya baik 
secara lisan maupun tulisan (Umar, 2012). Secara operasional, 4C ini dijabarkan dalam empat kategori langkah, yakni: Pertama, cara berpikir, termasuk berkreasi, berinovasi, bersikap kritis, memecahkan masalah, membuat keputusan, dan belajar pro-aktif. Kedua, cara bekerja, termasuk berkomunikasi, berkolaborasi, bekerja dalam tim. Ketiga, cara hidup sebagai warga global sekaligus local; dan keempat, alat untuk mengembangkan ketrampilan abad 21, yakni teknologi informasi, jaringan digital, dan literasi (Morocco, 2008).

Perangkat pembelajaran berbasis konsep ketrampilan abad 21 bagi peserta didik akan membekali dengan kemampuan-kemampuan komunikasi, kolaborasi, berpikir kritis dan pemecahan masalah, serta kreatif dan inovatif. Keterampilan tersebut merupakan keterampilan utama yang harus dimiliki dalam konteks abad ke-21 (Trilling\& Fadel, 2009: 48). Ditarik lebih jauh lagi 4C seharusnya muncul ketika pembelajaran menekankan student-centered dan bukan teacher-centered. Selain itu, pernah ada model yang disebut CBSA (Cara Belajar Peserta Didik Aktif). Semuanya itu, mendorong terbangunnya ketrampilan 4C dalam diri para peserta didik. Pentingnya tahap operasional pelaksanaan 4C ini melalui perangkat pembelajaran yang digunakan di sekolah akan membekali Peserta Didikakan ketrampilan abad 21 .

Kurangnya pengetahuan pada sejumlah guru yang tidak mampu mengoperasionalkan konsep pembelajaran dengan baik, yakni guru-guru hanya menggantungkan metode dan strategi pembelajaran pada buku pegangan atau dokumen-dokumen yang sudah diterima. Dampaknya peserta didik mengalami kesulitan dalam pemecahan masalah. Guru mengungkapkan bahwa peserta didik belum terbiasa menuliskan apa yang diketahui dan ditanyakan dalam soal, bahkan kebanyakan peserta didik tidak memahami soal dan tidak mengetahui bagaimana cara menyelesaikan masalah. Dengan memanfaatkan hasil penelitian pengembangan perangkat pembelajaran matematika yang berupa bahan ajar, LKPD, dan RPP berbasis keterampilan abad 21 yang layak digunakan dapat mengatasi permasalahan tersebut. Sehingga perlu diadakan sosialisasi dan implementasi terhadap hasil penelitian tersebut kepada masyarakat, khususnya para guru di sekolah menengah pertama 


\section{METODE PELAKSANAAN}

Secara umum, metode pelaksanaan pengabdian ini terdiri dari tiga tahapan:

1. Tahap Persiapan

Tahap persiapan ini terdiri dari mempersiapkan model perangkat pembelajaran yang berbasis keterampilan abad 21 serta penetapan jadwal pelaksanaan dan peserta.

2. Tahap Sosialisasi dan Implementasi

Kegiatan yang dilakukan adalah mensosialisasikan perangkat pembelajaran yang berbasis keterampilan abad 21 dalam bentuk Focus Group Discussion.

3. Tahap Evaluasi

Tanya jawab untuk mengecek pemahaman materi sosialisasi dan implementasi.

\section{HASIL DAN PEMBAHASAN}

Keterampilan Abad 21 yang dianggap bisa memperkuat modal sosial (social capital) dan modal intelektual (intellectual capital). Keterampilan abad 21 disingkat dengan 4C: Communication, Collaboration, Critical thinking and problem solving, Creativity and innovation. Berdasarkan hasil penelitian Siswa yang tahu keterampilan belajar abad ke21 ada $20 \%$ dan $13 \%$ dari mereka siap untuk mengambil keuntungan dari komputasi (Purwanto, 2012)

Critical Thinking (Berpikir Kritis), merupakan kemampuan untuk memahami sebuah masalah yang rumit, mengkoneksikan informasi satu denganinformasi lain, sehingga akan muncul berbagai perspektif, dan menemukan solusi dari suatu permasalahan. Critical thinking dimaknai juga sebagai kemampuan menalar, memahami dan membuat pilihan yang rumit; memahami interkoneksi antara sistem, menyusun, mengungkapkan, menganalisis, dan menyelesaikan masalah.Kemampuan membedakan kebenaran dari kebohongan, fakta dari opini, atau fiksi dari non-fiksi, merupakan salah satu modal bagi peserta didik untuk mengambil keputusan dengan lebih bijak sepanjang hidupnya.

Collaboration (Kolaborasi),kemampuan untuk bekerja sama, saling bersinergi, beradaptasi dalam berbagai peran dan tanggungjawab, bekerja secara produktif dengan yang lain,menempatkan empati pada tempatnya, dan menghormati perspektif berbeda.Dengan berkolaborasi, maka setiap pihak yang terlibat dapat saling mengisi kekurangan yang lain dengan kelebihan masing-masing.Akan tersedia lebih banyak pengetahuan dan keterampilan secara kolektif untuk mencapai hasil yang lebih maksimal.Teknologi yang tersedia saat ini membuat peluang peserta didik untuk berkolaborasi terbuka lebar tanpa harus dibatasi oleh jarak.Karena itu, anak-anak kita perlu dibekali dengan kemampuan berkolaborasi sebagai salah satu keterampilan abad 21 yang mencakup kemampuan bekerja sama secara efektif dalam tim yang beragam, fleksibel dan mampu berkompromi untuk mencapai tujuan bersama, memahami tanggung jawabnya dalam tim, dan menghargai kinerja anggota tim lainnya 
Communication (Komunikasi) adalah kegiatan mentransfer informasi, baik secara lisan maupun tulisan. Komunikasi merupakan hal penting dalam peradaban manusia.Tujuan utama komunikasi adalah mengirimkan pesan melalui media yang dipilih agar dapat diterima dan dimengerti oleh penerima pesan.Komunikasi dapat berjalan efektif jika pesan yang disampaikan oleh komunikator dapat diterima dengan baik oleh komunikan, sehingga tidak terjadi salah persepsi.Hadirnya gadget di era globalisasi dapat dijadikan sebagai media komunikasi yang efektif bagi anak-anak.Akan tetapi pengawasan, terutama dari orangtua perlu semakin ditingkatkan terhadap pemakaian gadget sebagai media informasi bagi anak-anakmereka, agar tidak disalahgunakan untuk hal-hal yang negatif. Selain itu, lamanya penggunaan gadget bagi anak-anak juga perlu dibatasi agar kompetensi sosialnya dengan teman-teman sebaya tetap terjaga.

Creativity (Kreativitas) merupakan kemampuan untuk mengembangkan, pelaksanakan, dan menyampaikangagasan-gagasan baru kepada yang lain; bersikap terbuka dan responsif terhadap perspektif baru dan berbeda.Kreativitas juga didefinisikan sebagai kemampuan seseorang dalam menciptakan penggabungan baru.

Kreativitas akan sangat tergantung kepada pemikiran kreatif seseorang,yaitu proses akal budi seseorang dalam menciptakan gagasan baru. Kreativitas yang bisa menghasilkanpenemuan-penemuan baru sering disebut sebagai inovasi.Era teknologi ditandai dengan semakin banyak pekerjaan yang diambil alih oleh mesin di masa depan.

Berpikir kreatif dalam menciptakan berbagai inovasi baru adalah salah satu keterampilan abad 21 yang akan membuat seseorang mampu bertahan dan tidak tergantikan oleh robot atau mesin di bidang pekerjaannya.

\section{KESIMPULAN}

Setelah dilaksanakan pengabdian kepada masyarakat di SMPN 23 Mataram, kemudian dilakukan wawancara dengan sampel acak sebanyak 7 peserta terkait dengan perangkat pembelajaran yang mendukung keterampilan abad 21, diperoleh bahwa sebelum pengabdian dilaksanakan peserta tidak pernah mendapatkan sosialisasi terkait dengan hal tersebut. Pengetahuan peserta tentang keterampilan abad 21 masih sangat minim hanya sebatas pernah mendengar kata-kata kreatif dalam kehidupan sehari-hari akan tetapi tidak pernah mendapat penjelasan lebih mendalam terkait dengan definisi, indicator dan perangkat pembelajaran yang mendukung keterampilan abad 21. Setelah pengabdian dilaksanakan maka peserta mendapatkan pengetahuan terkati dengan 4 kompetensi yang diperlukan pada abad 21 yang disingkat $4 \mathrm{C}$ beserta indicator dan perangkat pembelajaran yang mendukung pembelajaran abad 21. Selain itu peserta mendapatkan keterampilan dalam mengembangkan perangkat pembelajaran yang mendukung keterampilan abad 21.

\section{UCAPAN TERIMA KASIH}

Terimakasih Kepada Universitas Mataram yang telah mendanai kegiatan ini meluli PNBP Universitas Mataram. 


\section{REFERENSI}

Morocco, C.C., etal. (2008). Supported Literacy for Adolescents: Transforming Teaching and Content Learning for The Twenty-First Century. San Francisco: Jossey-Bass A WileyImprint.

Trilling, B. \& Fadel, C. (2009). 21st Century Skills: Learningfor Life in Our Times. San Francisco: Jossey-Bass A WileyImprint.

Choridah, D. T. (2013). Peran Pembelajaran Berbasis Masalah Untuk Meningkatkan Kemampuan Komunikasi Dan Berpikir Kreatif Serta Disposisi Matematis Siswa Sma. Infinity Journal, 2(2), 194. https://doi.org/10.22460/infinity.v2i2.35

Purwanto. (2012). Efek Google Dan Penguasaan Siswa Tentang Keterampilan Belajar Abad 21. 15(4), $480-487$.

Umar, W. (2012). Membangun Kemampuan Komunikasi Matematis Dalam Pembelajaran Matematika. Infinity Journal, 1(1), 1. https://doi.org/10.22460/infinity.v1i1.2 